Cómo citar este artículo / How to cite this article: Vargas-Vázquez, S., López Monteagudo, G. y San Nicolás Pedraz, M. ${ }^{a}$ P. (2021). La ambigüedad de los amores de Zeus en los mosaicos romanos de la Bética. Lucentum, XL, 215-229. https://doi.org/10.14198/LVCENTVM.18996

\title{
LA AMBIGÜEDAD DE LOS AMORES DE ZEUS EN LOS MOSAICOS ROMANOS DE LA BÉTICA
}

THE AMBIGUITY OF THE ZEUS’ LOVES IN THE ROMAN MOSAICS OF BAETICA

SEBASTIÁN VARGAS-VÁZQUEZ

Universidad de Sevilla, España

svargas2@us.es

https://orcid.org/0000-0002-6015-412X

GUADALUPE LÓPEZ MONTEAGUDO

Consejo Superior de Investigaciones Científicas, España

guadalupelopez@ih.csic.es

https://orcid.org/0000-0003-0106-5108

M. ${ }^{\mathrm{A}}$ PILAR SAN NICOLÁS PEDRAZ

Universidad de Educación Nacional a Distancia, España

psan@geo.uned.es

https://orcid.org/0000-0002-8958-1707

Recepción: 08/02/2021

Aceptación: 26/02/2021

\section{Resumen}

El fin que se persigue en el presente trabajo es hacer una lectura simbólica y metafórica de las representaciones de los Amores de Zeus en los mosaicos romanos de la Bética, poniendo de manifiesto las particularidades iconográficas y la contaminación con otros ciclos mitológicos. Se profundiza en las formas de representar las distintas escenas del mito, en ocasiones dominadas por la ambigüedad y el juego al despiste, factores estos últimos especialmente presentes en los mosaicos de Écija. Se resalta, asimismo, el carácter «amable» de las representaciones, en las que domina el juego del amor, del cortejo y de la seducción, así como la sexualidad y el consentimiento que reina sobre cualquier rasgo o síntoma de violencia.

Palabras claves. Simbolismo; Europa; Ío; Leda; Ganimedes; Dánae; Antíope; toro; cisne; águila; lluvia de oro; sátiro; contaminación.

\begin{abstract}
This paper aims to symbolically and metaphorically analyze the depictions of Zeus' love affairs in the Roman mosaics of Baetica, focusing on the iconographical features and its contamination with other mythological cycles. This research highlights different ways of depicting the various scenes of this myth, in which ambiguity and vagueness are outstanding. These factors are particularly evident in the mosaics of Écija. In addition, it is also highlighted that love games, courtship, seduction, sexuality, and consent are elements that prevail over any violent feature.
\end{abstract}

Key words. Symbolisme; Europa; Ío; Leda; Ganimedes; Dánae; Antíope; bull; swan; eagle; golden shower; satyr; contamination. 


\section{INTRODUCCIÓN}

Como ocurre con tantos otros temas, la Bética es la zona de Hispania donde más referencias relacionadas con los amores de Zeus se han documentado. En su mayor parte se trata de mosaicos localizados en contexto urbano, destacando claramente Itálica y Écija, las ciudades que mayor número de ejemplares nos ha dejado y también los más bellos. Se trata por lo general de pavimentos que engalanan las salas más representativas de las domus y villae, en ocasiones cubicula de gran porte que dan idea del alcance cultural y del poder económico de los domini, aunque no solo estos espacios se destinan a acoger este tipo de representaciones.

En los mosaicos de la Bética el tema de los amores de Zeus presenta, en algunos casos, un tratamiento iconográfico y artístico singular que, unido a su confrontación con las fuentes literarias, conduce a una lectura de carácter ideológico y metafórico o alegórico. El tratamiento del relato mitológico y las particularidades artísticas, diferentes a las que presentan otras zonas, están relacionados con los talleres y con los artistas y, sobre todo, con los comanditarios que, en definitiva, son los responsables de la elección de los temas y del juego intelectual al que invitan las imágenes.

De los distintos episodios de los mitos y sus variadas iconografías la musivaria hispano-romana ha dado numerosos ejemplos, la mayoría procedentes de la Bética, región en la que se contabilizan 25 representaciones de los Amores de Zeus, concentradas en 13 mosaicos, dentro de la iconografía tradicional, pero también con unas peculiaridades muy de resaltar debidas seguramente a la idiosincrasia de la zona, la Bética en el caso que nos ocupa, probablemente reflejadas en cartones existentes en los talleres musivarios, invenciones del artista o del taller, o bien elegidas por deseo explícito de los propietarios de las mansiones cuyos suelos adornan, y que de esta forma manifiestan sus conocimientos de las distintas versiones literarias (López Monteagudo, 2010: 16-189; López Monteagudo y San Nicolás, 1995: 383-438; San Nicolás, 2011: 323-342; 2010: 497-518; 2006: 148-157; 2005-2006: 239-257; 1999: 347-390).

Y a este respecto hemos de preguntarnos el porqué de esta incidencia en esa zona de Hispania y el porqué de la variedad de iconografías para figurar un mismo mito. Son preguntas que en el caso de Europa, cuya presencia se halla atestiguada en siete mosaicos de los 13 contabilizados, tienen una explicación basada en la tradición semítica y en la asimilación de Europa con Astarté, en un posible sincretismo en regiones en donde existía un fuerte arraigo del culto oriental a Astarté desde la época de las colonizaciones. Y precisamente el toro era una de las formas del dios El, que atravesó el mar junto a su paredros Astarté, según relata Luciano de Samosata (dea. syr. 4) (López Monteagudo y San Nicolás, 1996: 451-470). Para el resto de los «amores» se puede suponer una deliberada intención por poner de manifiesto, de manera alegórica, la fecundidad y la riqueza que proporcionan las uniones «místicas», el hiérogamos entre lo divino y lo humano. Y todo ello en una zona de gran riqueza agrícola como es la Bética.

A partir de las imágenes figurativas, de su contexto arqueológico y de sus aspectos cronológicos, los mosaicos adquieren el valor de documentos históricos que nos transmiten un mensaje de carácter socio-político y económico (aspectos tratados en Vargas-Vázquez, López Monteagudo y San Nicolás, e.p.). Las escenas plasmadas en los pavimentos musivos son una forma de representación social del dueño de la domus y una exposición de sus gustos y de sus conocimientos literarios, con lo que pretende llevar a sus invitados a desentrañar el mensaje oculto en esas imágenes encriptadas, cuya lectura hemos procurado hacer con las reflexiones expuestas a continuación.

\section{ANÁLISIS ICONOGRÁFICO E INTERPRETA- TIVO}

Los mosaicos de los Amores de Zeus de la Bética destacan por la variedad de los tipos iconográficos, que no son exclusivos de esta región salvo algunas excepciones. Recordemos los raptos de Europa y Ganimedes o el juego amoroso entre Leda y el cisne, Antíope y el sátiro, prestándose a ese doble juego de sorpresa y miedo, de asombro y de aceptación, de danza erótica que preludia la consumación amorosa y placentera, pues como dice Ovidio:

\footnotetext{
«(...) Aunque diga que la has poseído con violencia, no te importe; esta violencia gusta a las mujeres: quieren que se les arranque por la fuerza lo que desean conceder. La que se ve atropellada por la ceguedad de un pretendiente, se regocija de ello y estima su brutal acción como un rico presente, y la que pudiendo caer vencida sale intacta de la contienda, simula en el aspecto la alegría, más en su corazón reina la tristeza (...)» (Ovid. am. I, 673-680).
}

No es solo la naturaleza poliédrica del dios y su comportamiento ambiguo, sino las formas de representar a Zeus y a sus amores lo que llama la atención en los mosaicos de la Bética, en las que hay un juego premeditado de metáforas, de desdoblamientos, de acertijos, de ocultaciones, de préstamo de identidades. Todo ello y su contaminación con otros ciclos mitológicos y con conceptos abstractos alegóricos, como las estaciones, inducen al espectador a un ejercicio mental que desborda los límites de la lógica y se adentra en un laberinto de suposiciones, en el que el lenguaje en clave es fundamental. También las doncellas participan, como el dios, del engaño y de la ambigüedad en sus amoríos, escondiéndose bajo figuras de animales, vaca y osa en los casos de Ílo y Calisto, son suplantadas por otros personajes como Egina por su padre, o toman la apariencia de nereidas en el caso de Europa y de bacantes en el de Antíope. 


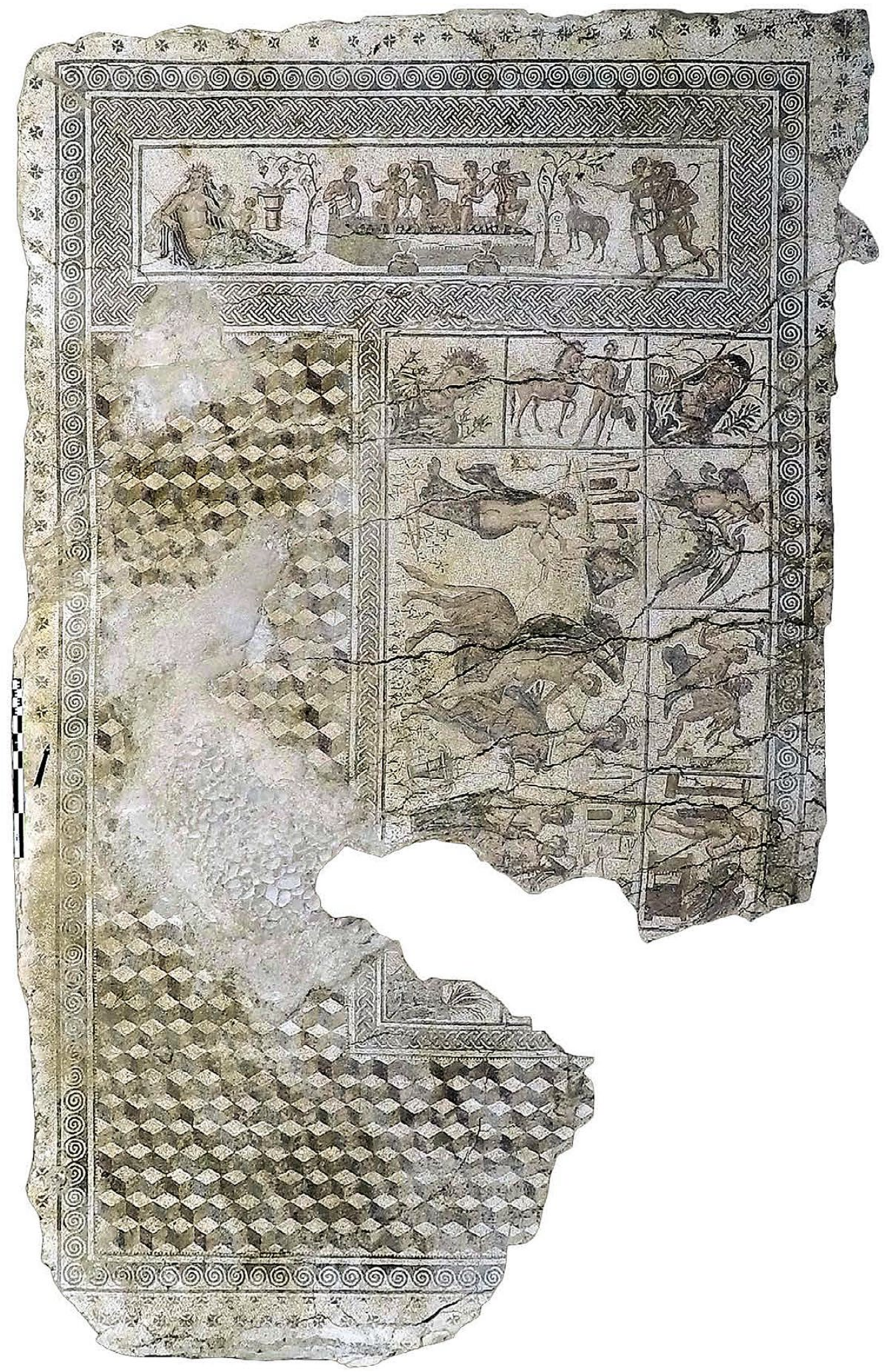

Figura 1: Mosaico de los Amores de Zeus de Écija. Foto cortesía de Sergio García-Dils

En la Bética hay otras representaciones en las que el dios figura con una iconografía no transformada o transformadora, sino ambigua, adoptando una imagen contaminada y en ocasiones prestada. Nos estamos refiriendo al episodio de Dánae y la lluvia de oro figurada en el mosaico de los amores de Zeus de Écija (GarcíaDils y Ordóñez, 2019: 27-28). En nuestra opinión, Zeus aparece claramente como una figura recostada junto a una roca o fuente de la que mana agua (Figs. 1 y 2), con la iconografía típica de los dioses-ríos. Pero 


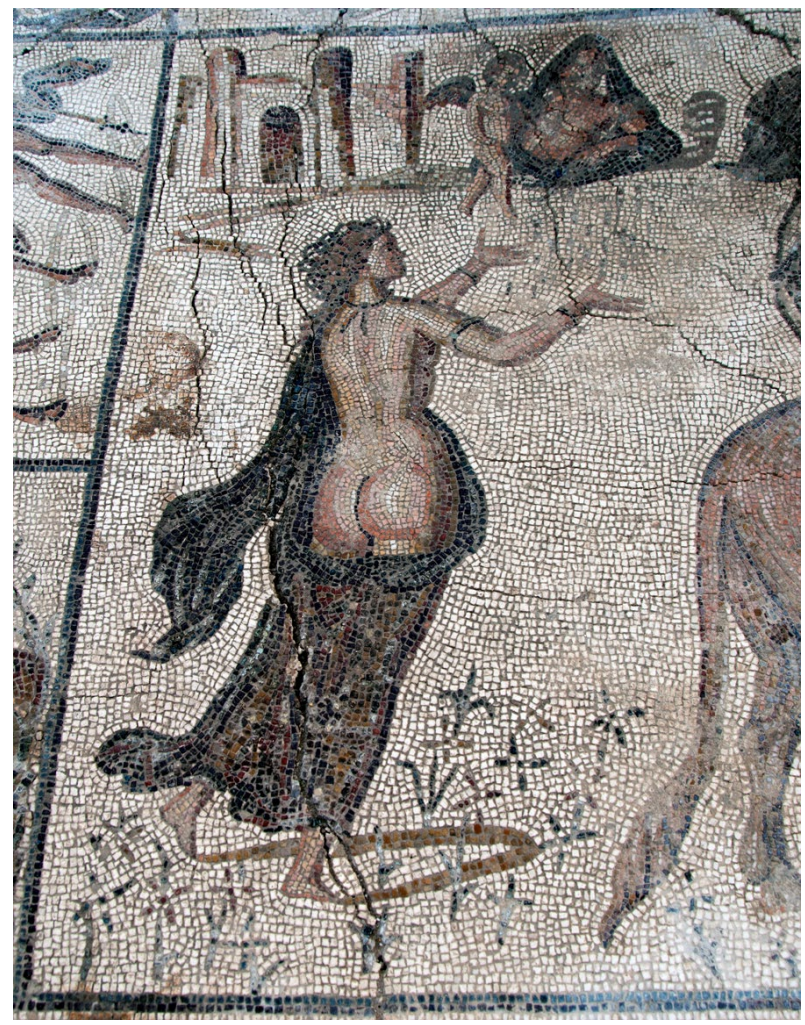

Figura 2: Mosaico de los Amores de Zeus de Écija. Detalle. Foto cortesía de Sergio García-Dils

la presencia del eros hace que el agua se transforme en lluvia de oro que cae del cielo y es recogida en sus manos por Dánae. Una forma muy delicada y elegante de representar la seducción de la joven que, por lo general levanta su manto para que el semen entre en ella y la fecunde, caso de los mosaicos de Itálica, de Beyrouth y de Cartago, imágenes de un elevado erotismo y contenido sexual. Esta representación constituye, por tanto, un unicum en la musivaria astigitana, equiparable a la del mosaico argelino de Ouled Agla, en la que desde una vasija que figura junto a Dánae, alusión al mismo Zeus, emana la lluvia de oro.

En este mosaico astigitano hay otro ejemplo de préstamo de identidad por parte del dios que asume la imagen de Hermes, hijo de los amores de Zeus con la pléyade Maya, para acudir al encuentro de Ío, representada con su aspecto humano como figura también en el mosaico de Torre de Palma junto a su guardián Argos, o en el mosaico policromo procedente de la Casa del Red Pavement de Antioquía, en el Museo de Hatay (Levi, 1947: 75-80). Hermes figura al lado de las dos compañeras de Europa, pero en un plano ligeramente más alto (Fig. 3), grupo que ha sido interpretado en el contexto del Rapto de Europa (García-Dils y Ordóñez, 2019: 23) $\mathrm{y}$ al que nosotros damos una lectura en relación con el mito de Zeus e Ío, un artificio utilizado para aludir a otro de los Amores del dios. Son muchas las representaciones antiguas en las que Hermes, enviado por Zeus para auxiliar y liberar a la hija de Ínaco, aparece representado junto a ella, mostrándose esta última en forma de vaca, como puede verse en el ánfora de pinturas negras de Exekias del British Museum o el stamnos de Hermes dando muerte a Argos de los cien ojos del Kunsthistorisches Museum de Viena, de principios de siglo $\mathrm{V}$ a. C., o en forma humana, como la vemos en el oinochoe de Ílo y las Danaides del Kunsthistorisches Museum de Viena, de hacia el 463 a. C., y en un fresco procedente del Ekklesiasterion del Templo de Isis de Pompeya, conservado en el Museo Arqueológico Nacional de Nápoles. En el caso del mosaico de Écija, esta última habría sido la forma de representar a Ío, si bien, las pérdidas que sufre la figura del personaje no permiten vislumbrar con detalle si fue plasmada con pequeños cuernos en la frente. En este sentido, Hermes corre desde Zeus, figurado en forma de río en la parte superior de la escena, hacia Ío, que con los brazos extendidos espera a su libertador, mostrándose de forma destacada en un nivel superior al de aquellas figuras femeninas que dan espigas al toro del Rapto de Europa. Es interesante ver cómo ambos personajes, Dánae e Ío, enmarcan la escena del Rapto de Europa con ese gesto simbólico de alzar los brazos para de algún modo recibir a Zeus, adquiriendo, ahora sí, mayor justificación y significado la presencia de Hermes, que corre hacia la derecha en dirección inequívoca hacia Ío, cerrando así todo un ciclo dedicado a los amores de Zeus. En ambas escenas la presencia encriptada del dios se hace bajo apariencias diversas, de un río o el del intermediario de Zeus para sus conquistas amorosas. De esta forma, el grupo de Zeus/Hermes e Ío contiene al mismo tiempo el sentimiento de atracción y de liberación. Todo en este mosaico es juego amoroso, encuentro, cortejo, atracción, seducción consentida y consumación, sin violencia, sin acoso, con erotismo, igual que ocurre en el mosaico de los Amores de Itálica (Fig. 4), pero con la particularidad de que en Écija se juega al despiste, al engaño, a la confusión, al aparentar una cosa y ser otra, en definitiva como una suerte de acertijo.

En los mosaicos de la Bética hay otras sustituciones del dios, otras imágenes prestadas dentro del conjunto de los Amores, lo que no deja lugar a dudas en cuanto a su significado, como ocurre en el mosaico de los Amores de Itálica (Fig. 4) y en el de Fernán Núñez, mosaico cuyo fragmento mejor conservado es el panel que contiene la escena del rapto de Europa (Fig. 5). En ambos pavimentos, el rapto de Egina por Zeus se ha representado mediante la figura del río Asopo, padre de la joven, y en el de Itálica, además, la presencia de Zeus se encuentra implícita en el relato de Calisto. Lo mismo puede decirse del busto de Argos que preside el mosaico de los Amores de Itálica en sustitución de Zeus y sus amoríos con Ío, la cual ocupa uno de los compartimentos en forma de vaca con la media luna sobre su lomo. Todas estas particularidades hacen de los mosaicos de la Bética con los amores de Zeus un hápax dentro de la musivaria romana, como también lo es la conjunción en una misma escena del rapto de Europa por el toro y del rapto de Ganimedes por el águila de Zeus en el mosaico 


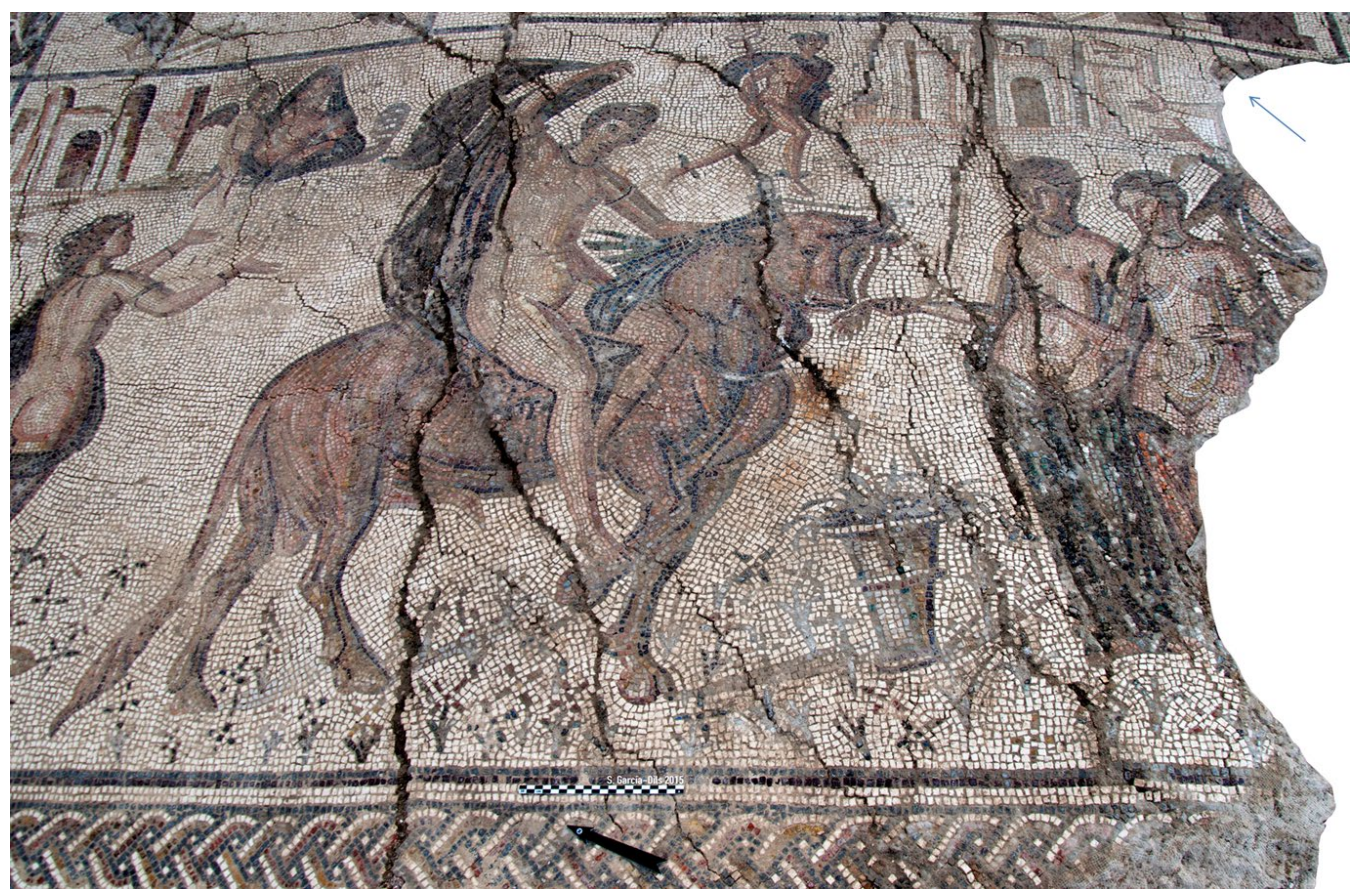

Figura 3: Mosaico de los Amores de Zeus de Écija. Detalle. Foto cortesía de Sergio García-Dils. La flecha azul marca la presencia de Ío

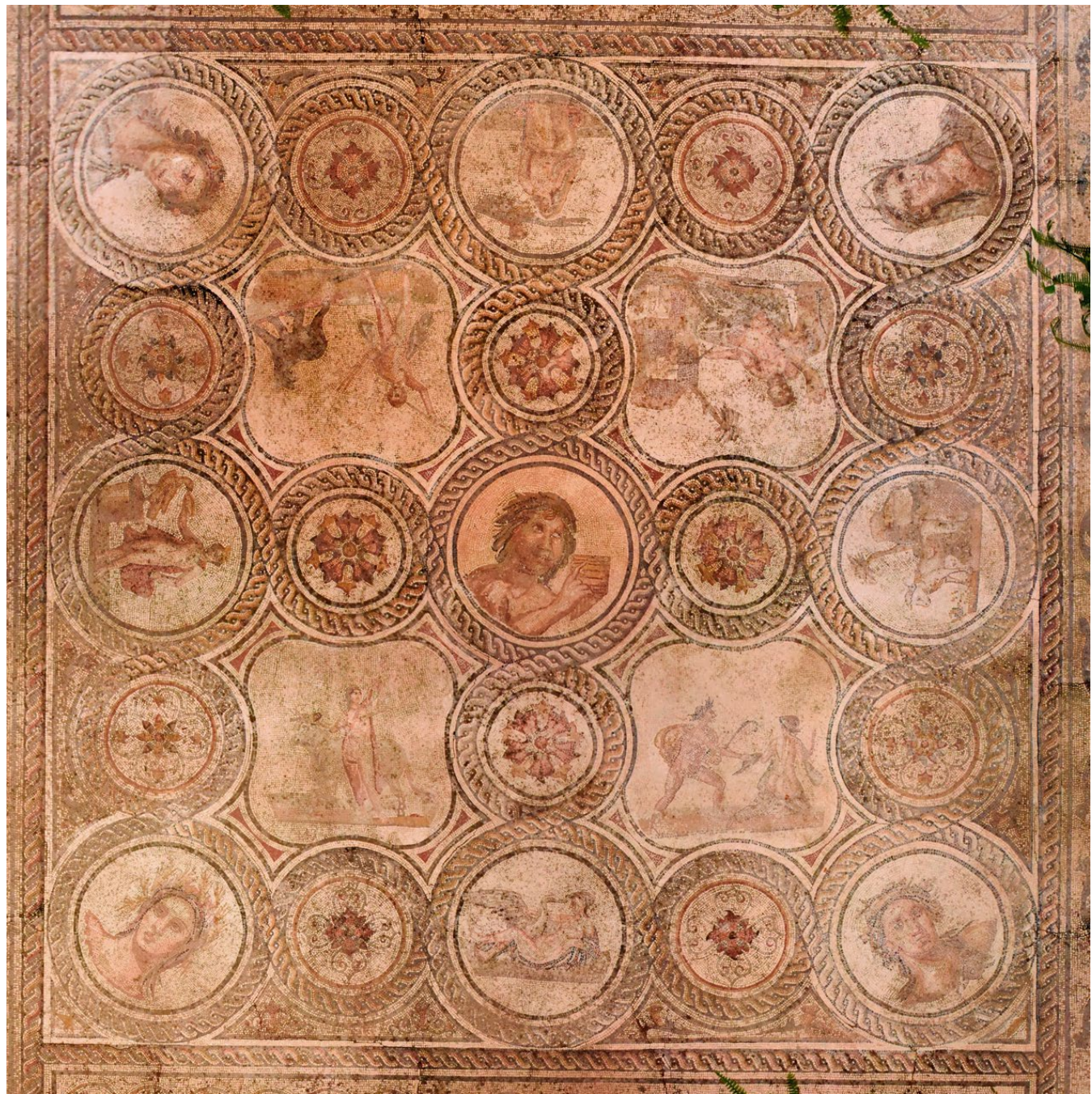

Figura 4: Mosaico de los Amores de Zeus de Itálica. Foto Alberto Villarejo y Sebastián Vargas-Vázquez 


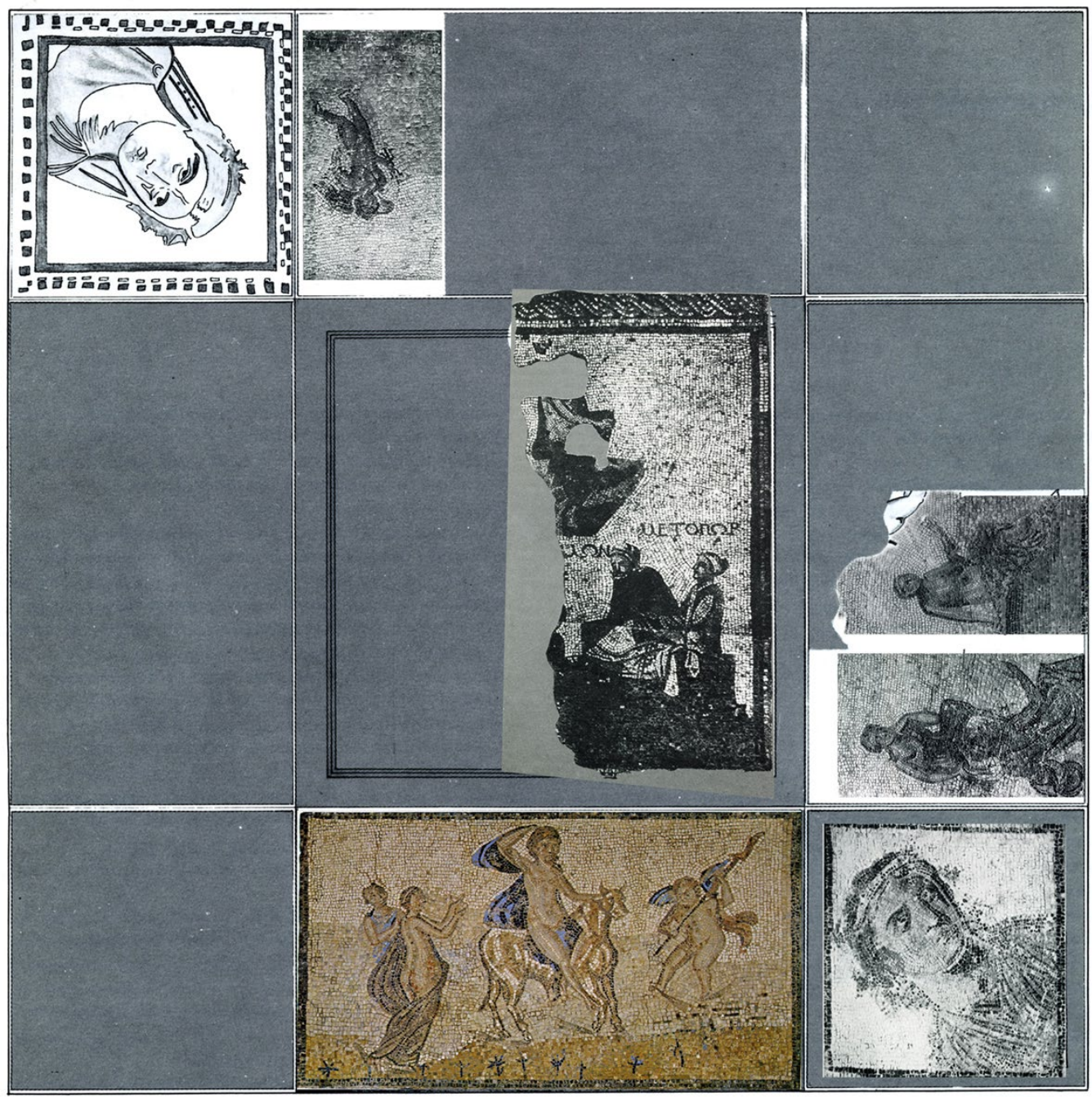

Figura 5: Mosaico del Rapto de Europa de Fernán Núñez. Foto M. ${ }^{a}$ Pilar San Nicolás

de la C/ San Juan Bosco de Écija (Fig. 6). Este doble rapto constituye un unicum en las representaciones musivas romanas, aunque no en otros soportes como el vaso de vidrio de Bagram, datado en el s. I d. C. Europa y Ganimedes también figuran juntos en el mosaico de las Estaciones de Corduba (Blázquez, 1981: 27) (Fig. 7), interpretado por D. Fernández Galiano (1982: 19) como otra representación de los Amores de Zeus, en el que ambos personajes asumen el papel alegórico de las Estaciones.

$\mathrm{Y}$ a este respecto hay que señalar que la iconografía adoptada en algunos mosaicos de la Bética no responde a la casualidad, sino que es fruto de una intencionada simbología. Recordemos los tipos iconográficos utilizados para representar a Europa, a Leda y el cisne, a Dánae, incluso a Ganimedes. En Écija la representación de las figuras vistas de espaldas conlleva un grado de sensualidad supremo, es la aceptación del acto sexual. $\mathrm{Si}$ en el viaje marítimo de la C/ San Juan Bosco Europa aparece cabalgando sobre el toro de frente, con temor o con complacencia revelando el cambio en sus sentimientos, cuando aparece de espaldas flotando sobre el dorso del animal, tal y como figura en el mosaico de la C/ Espíritu Santo (Figs. 8 y 9) y también en el de Cos, del siglo III, es que ya ha aceptado su entrega, es el climax de su unión amorosa con el dios. Y lo mismo puede decirse de Leda, quien en las dos representaciones astigitanas, mosaicos de los Amores de la Plaza de Armas (Fig. 1) y del Triunfo de Baco de la Plaza de Santiago (Fig. 10), figura de espaldas realizando el acto sexual con el cisne, aunque la belleza de las imágenes aminore la crudeza de la situación. Y qué decir de Dánae, representada en el mosaico de los Amores de Itálica (Fig. 4), como es habitual, sentada levantando su himation para que la penetre la lluvia de oro que desde lo alto le envía el dios, un tipo iconográfico de un realismo intenso, pero que en el mosaico de los Amores de Écija se ha sustituido por la delicada imagen de Dánae, vista de espaldas y alzando sus manos para recibir la lluvia de oro, con un simbolismo sexual idéntico como indica su cuerpo desnudo visto de espaldas.

$\mathrm{Y}$ es que en el arte del mosaico no llaman tanto la atención los atributos femeninos de las jóvenes, como los senos que suelen ser de pequeño tamaño y a veces es difícil distinguir el género de la imagen representada, cuya identidad resulta ambigua cuando el sexo 


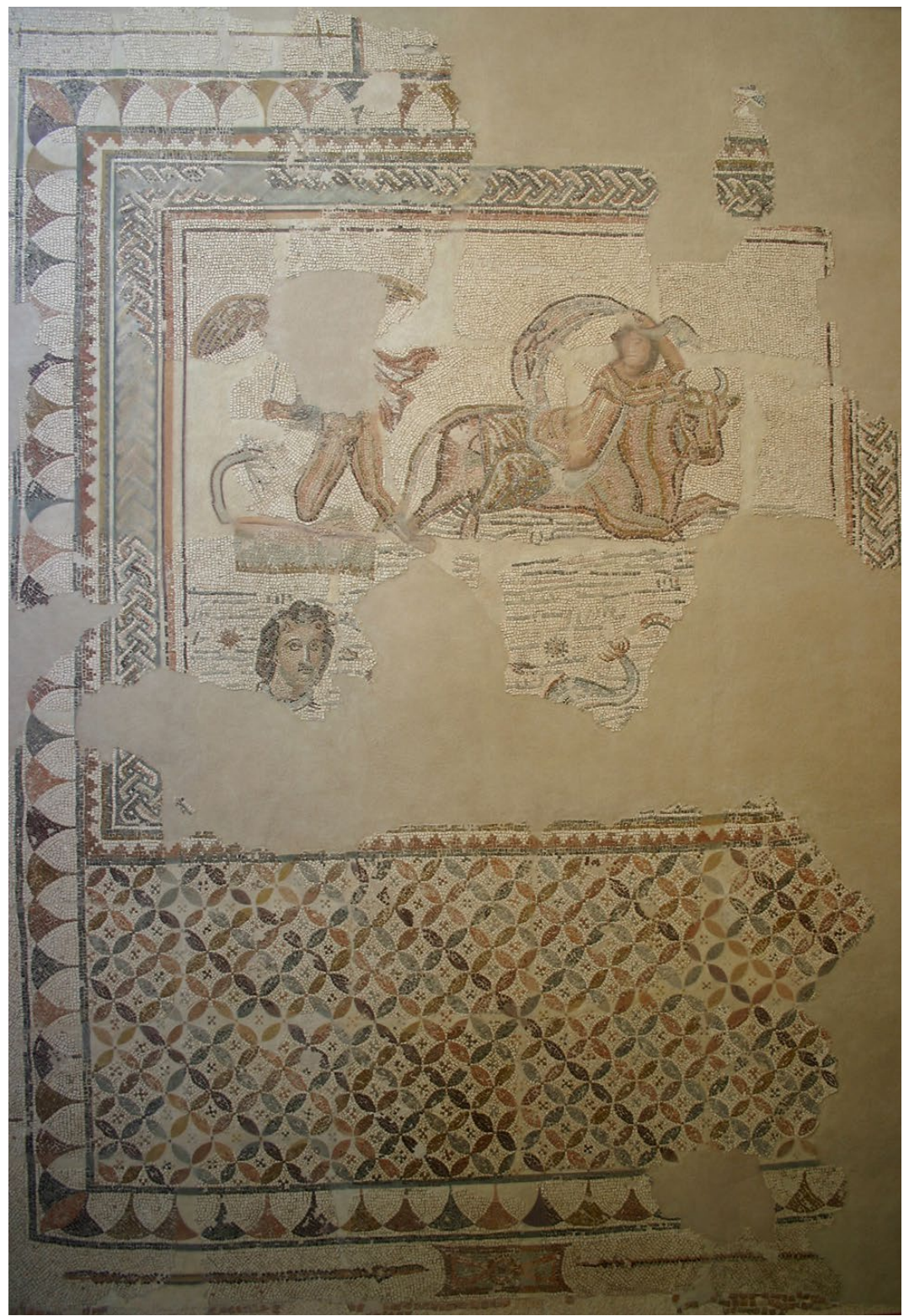

Figura 6: Mosaico del Rapto de Europa y Ganimedes de la calle San Juan Bosco de Écija. Foto Sebastián Vargas-Vázquez

no está indicado de manera explícita. Por el contrario, se marcan más las caderas y el erotismo se concentra en la parte posterior de la figura, la espalda y las nalgas de forma redondeada y por este motivo cuando la joven se presenta de esta forma, es que ya ha accedido a los deseos sexuales de su amante y ha aceptado la consumación plena de la unión amorosa. Lo mismo puede decirse de la figura de Ganimedes en el mosaico de los Amores de Écija (Fig. 1), visto de espaldas, cuyo sensual desnudo con sus formas redondeadas y carnosas recuerda una iconografía casi femenina. Y también las nereidas en otro mosaico de Écija, en la misma postura, exhibiendo su cuerpo desnudo de voluptuosas, carnosas y eróticas formas. El tipo iconográfico visto de espaldas se extiende a Antíope en otros lugares de la Bética, sorprendida por el sátiro en el mosaico de los Amores de Zeus de Itálica (Fig. 4) y danzando con el dios convertido en sátiro en el pavimento de Torre de
Benagalbón (Fig. 11), única representación acompañada con el epígrafe que desvela inequívocamente la identidad de los personajes (Mañas y Vargas-Vázquez, 2007: 327-328). Ambas figuras, identificadas como sátiro y ménade danzantes (Blanco, 1978: 39), pero que nosotros interpretamos como una posible representación de Zeus/sátiro y Antíope, aparecen asimismo vistas de espaldas en otro mosaico de Itálica conservado en la Casa Palacio de la Condesa de Lebrija en Sevilla (Fig. 12).

El tipo iconográfico visto de espaldas al parecer está inspirado en una pintura helenística de Apeles, ya que según Plinio ( $N H \mathrm{XXXV} \mathrm{79;} \mathrm{94),} \mathrm{este} \mathrm{pintor}$ se distinguía por «la gracia de su arte y por sus personajes vistos de espaldas», que debía figurar junto a otros cuadros traídos de Alejandría por Octavio hacia el 30 a. C., como el de Cadmos y Europa de Antifiles (ca. 300 a. C.), que decoraba el pórtico de Pompeyo en 


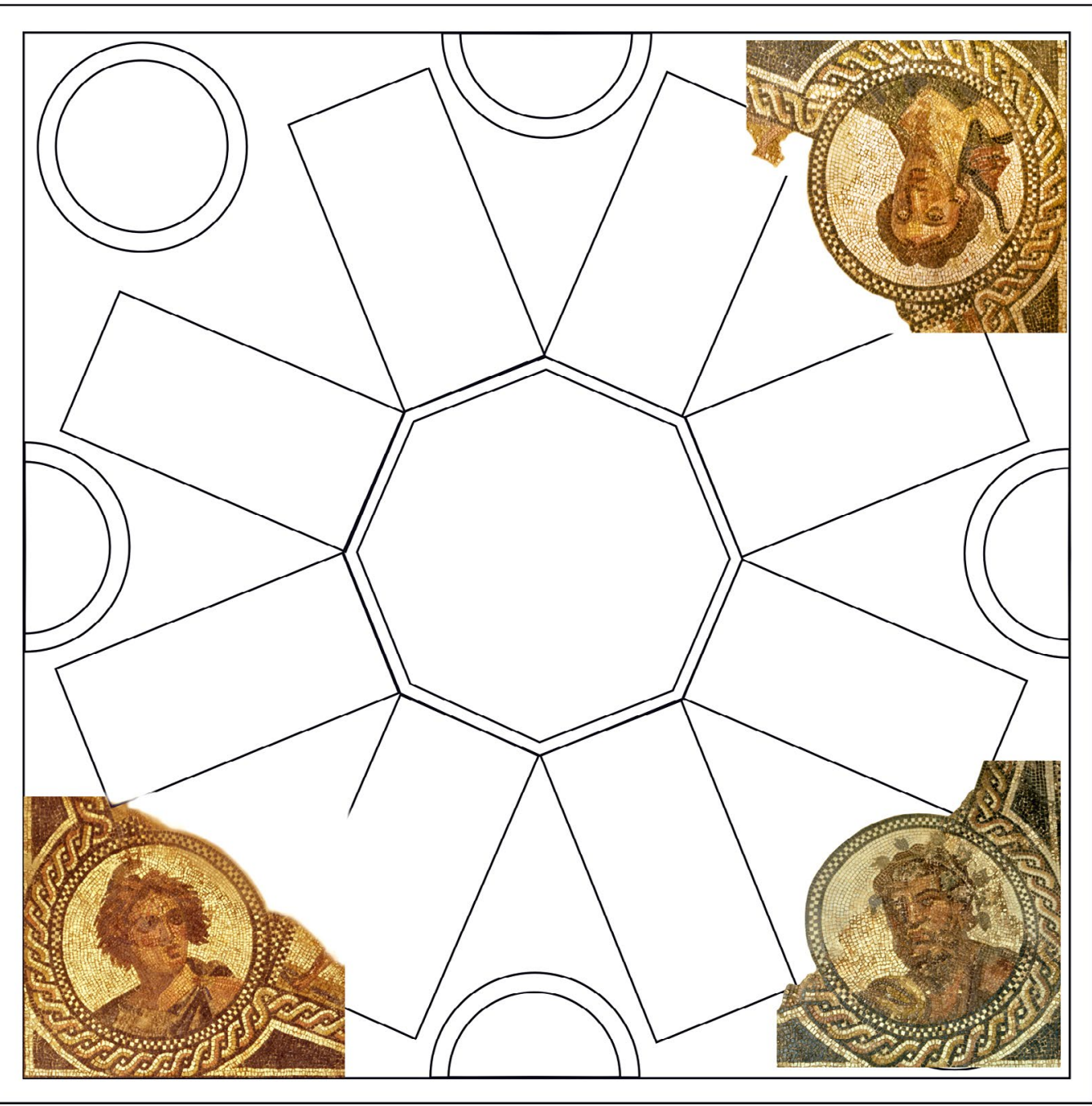

Figura 7: Mosaico de las Estaciones de Córdoba. Foto Guadalupe López Monteagudo

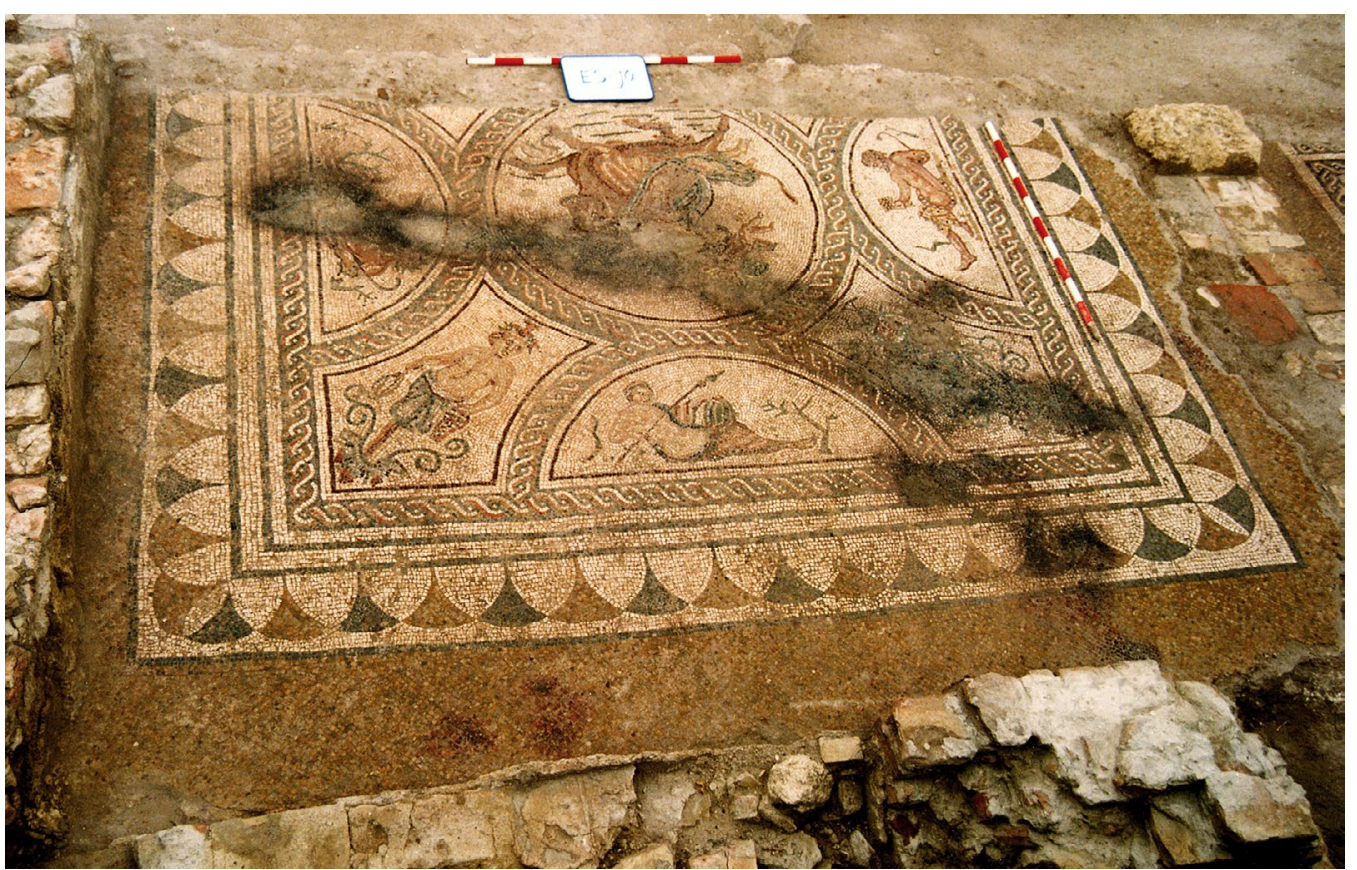

Figura 8: Mosaico del Rapto de Europa de la calle Espíritu Santo de Écija. Foto cortesía de Esther Núñez 


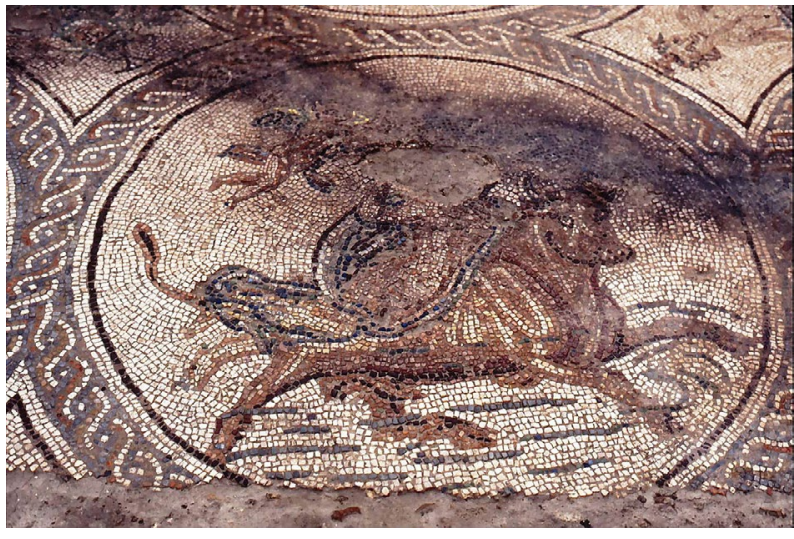

Figura 9: Mosaico del Rapto de Europa de la calle Espíritu Santo de Écija. Detalle. Foto cortesía de Esther Núñez

Roma (Plin. NH XXXV 114), o las escenas del Rapto de Europa expuestas en el templo del divino Augusto y en el pórtico de Europa en el Campo de Marte (Mart. epigr. XIV 180; II 14). No puede decirse que esto sea un axioma. A veces los desnudos femeninos vistos de frente, como Venus en el mosaico del Juicio de Paris de Casariche, tiene una gran carga erótica al mostrar en su desnudo integral no solo los senos, sino el sexo de manera explícita, como ocurre en el mosaico del Triunfo de Baco y Ariadna de Sabratha, en el del suplicio de Dirce de Écija (Vargas-Vázquez, López Monteagudo y García-Dils, 2017: 35-37, figs. 1 y 2) y en el Rapto de Europa de Itálica (Fig. 13) (Mañas, 2011a: 81-83).

El mosaico astigitano de los Amores de Zeus destaca no solo por su belleza artística y su depurada técnica, sino y sobre todo, por la delicadeza del leguaje narrativo. La escena principal que constituye los prolegómenos del rapto de Europa, en la que la princesa está montada sobre el toro y sus compañeras le ofrecen flores, es un ejemplo de galantería y al mismo tiempo de inocencia, como lo es también la figura de Ganimedes vista de espaldas dando de beber al águila. Incluso los cuadros con Leda y el cisne, Antíope y el sátiro, a pesar

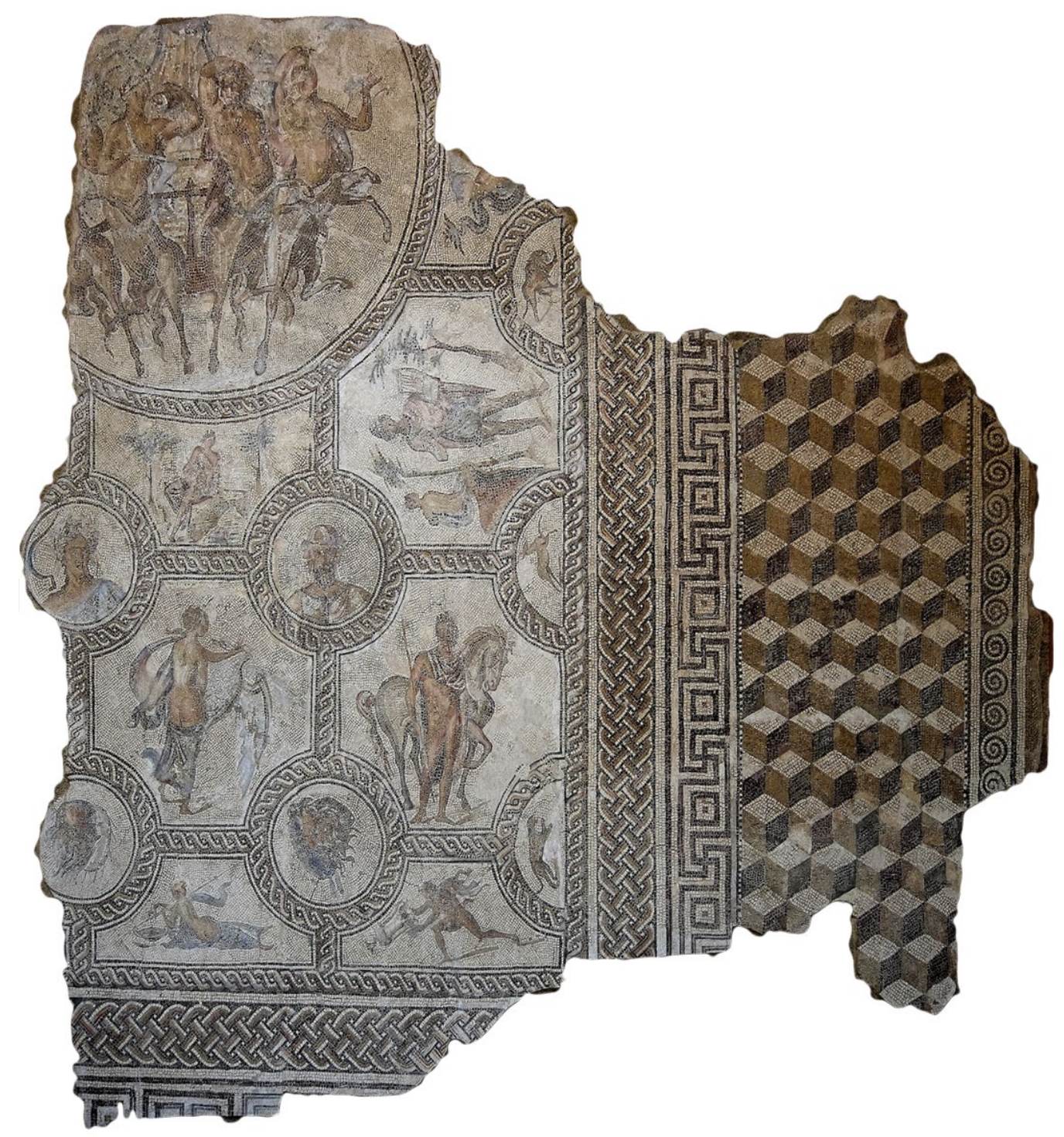

Figura 10: Mosaico del Triunfo de Baco de la Plaza de Santiago de Écija. Foto Sebastián Vargas-Vázquez 


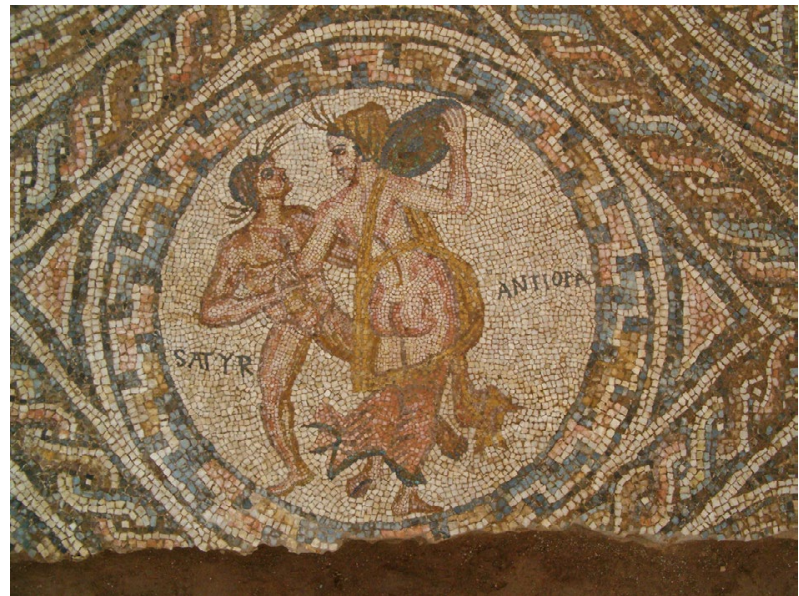

Figura 11: Mosaico de la villa romana de la Torre de Benagalbón. Detalle. Foto cortesía de Juan Bautista Salado Escaño

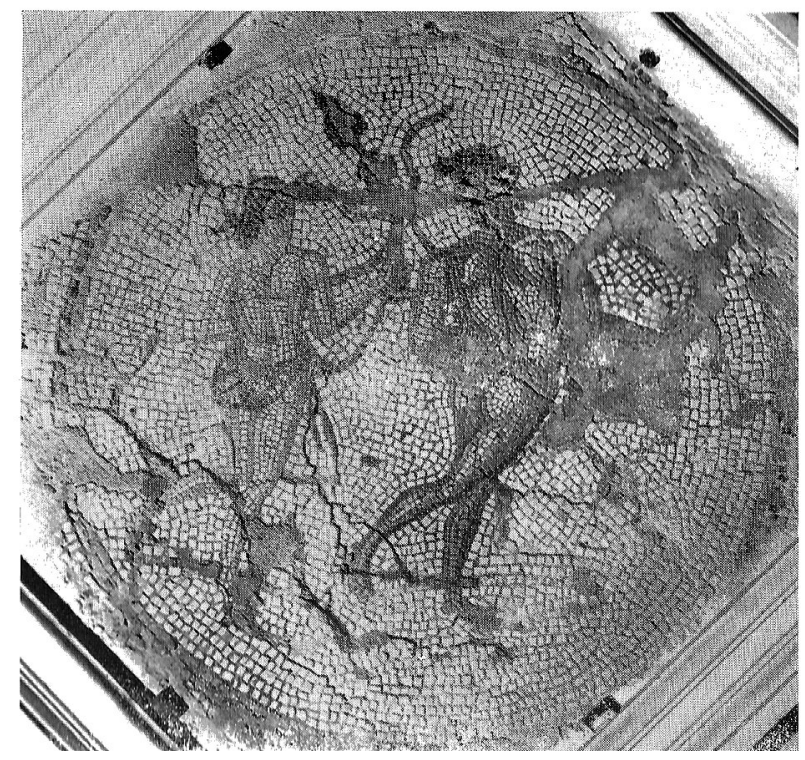

Figura 12: Medallón de mosaico de Itálica, conservado en la Casa Palacio de la Condesa de Lebrija (Blanco, 1978: lám. 41)

de su gran carga erótica, están desprovistos de agresividad y violencia. No hay rapto de Ganimedes ni de Europa. Hay aceptación en Dánae y entrega en Leda. Atracción en el de Antíope e Ío. Incluso en las imágenes báquicas, hay descubrimiento de Ariadna (VargasVázquez, López Monteagudo y García-Dils, 2017: 82; Vargas-Vázquez, 2018: 319). En ningún momento las escenas amorosas comportan violencia o acoso. Es más, se muestran los episodios del encuentro que preludian la unión carnal, a excepción de Leda y el cisne cuya iconografía es ya la consumación sexual y, por este motivo, figuran los dioscuros como fruto de esa unión, lo mismo que ocurre en el otro mosaico astigitano del Triunfo báquico de la Plaza de Santiago (Fig. 10); o la etapa posterior al rapto en el caso de Ganimedes en los mosaicos de los Amores de Écija (Fig. 1) y de Itálica (Fig. 4), que muestran al joven ya como copero de los dioses y en los que Zeus se muestra bajo su apariencia de águila como recuerdo del rapto. Esta doble

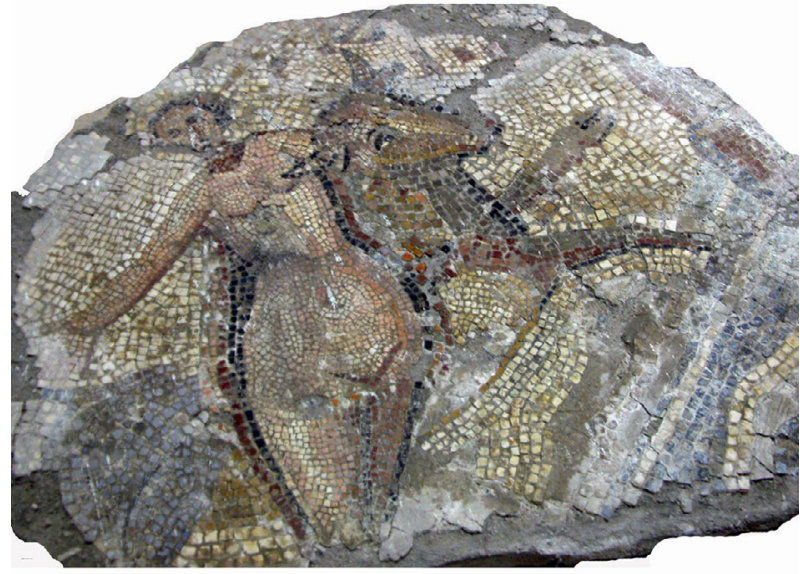

Figura 13: Mosaico del Rapto de Europa de Itálica. Foto cortesía de Irene Mañas

personalidad del dios se hace patente en el mosaico argelino con la representación de los Amores de Ouled Agla en el que el grupo formado por Ganimedes y Zeus en figura humana aparece acompañado por el águila utilizada para perpetrar el rapto. En otros soportes, como en la trulla/cazo de Cullera, también figura Júpiter en el asa presidiendo las distintas metamorfosis con la iconografía clásica de hombre maduro portando el rayo y el cetro (San Nicolás, 2006: 148-159).

\section{CONTAMINACIÓN TEMÁTICA Y ESPACIAL}

La contaminación de los amores de Zeus con otros ciclos mitológicos es relevante en el caso dionisiaco, y no solamente porque los personajes y los mitos aparezcan juntos en un mismo mosaico o formen parte del mismo programa decorativo, sino porque ideológicamente existe una ambigüedad muy grande en algunos personajes y en los mismos mitos. Lo dionisiaco impregna todo o casi todo como hemos tenido ocasión de resaltarlo en el caso de los mosaicos de Écija, pero también en Itálica y en otros lugares de la Bética. En Écija los dos pavimentos con el Rapto de Europa (Figs. 6,8 y 9), formaban parte del programa iconográfico de carácter báquico de dos casas romanas del s. III, mientras que el gran mosaico de los amores de Zeus (Fig. 1) pavimentaba el triclinium de la domus del mosaico de la doble cabeza báquica (Vargas-Vázquez, López Monteagudo y García-Dils, 2017: 77-83). En Itálica el mosaico de los Amores de Zeus (Fig. 4) decoraba, junto a dos presididos por el busto de Baco, una de las tres salas en paralelo de una domus urbana, tal vez el triclinium (Mañas, 2010: 214-216).

Pero esa contaminación no es solamente espacial, afectando al programa iconográfico de diferentes casas, sino que en los mosaicos de la Bética también es frecuente la combinación de personajes báquicos con otros de los amores de Zeus, como ocurre con las ménades y sátiros que ocupan las lunetas en el gran mosaico astigitano del Triunfo de Baco de la plaza de Santiago 


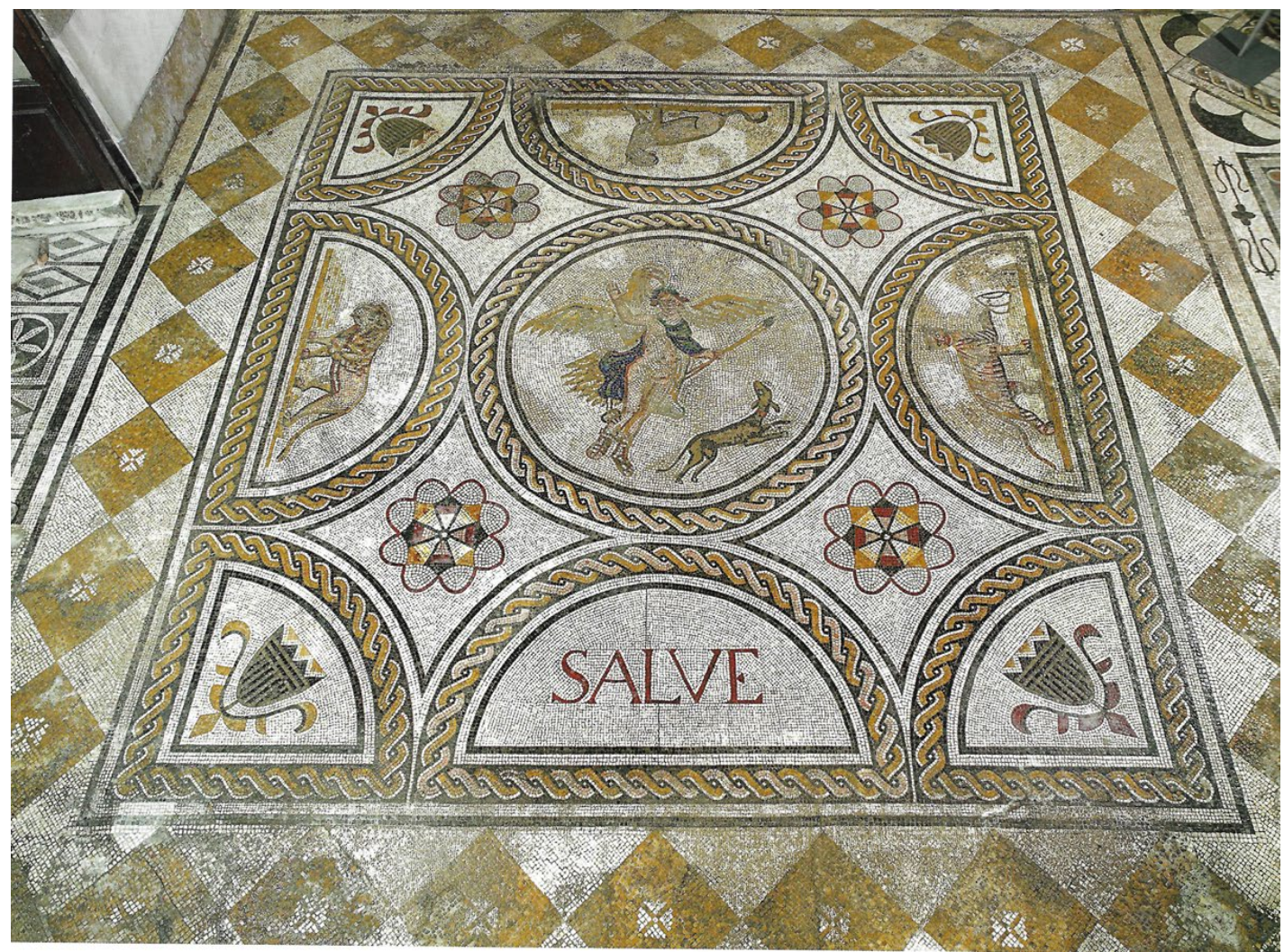

Figura 14: Mosaico de Ganimedes de Itálica, conservado en la Casa Palacio de la Condesa de Lebrija (López Monteagudo, 2010: 40)

(Fig. 10) y en el del Rapto de Europa de la calle Espíritu Santo (Fig. 8), o los animales báquicos que acompañan a la imagen de Ganimedes en el mosaico de Itálica de la Casa Palacio de la Condesa de Lebrija en Sevilla (Fig. 14), así como el descubrimiento de Ariadna y la presencia del lagar en el mosaico de los Amores de Zeus de la Plaza de Armas (Fig. 1) (Vargas-Vázquez, López Monteagudo y García-Dils, 2017: 82). Del mismo modo, el medallón de la Casa Palacio de la Condesa de Lebrija (Fig. 12) parece que compartía espacio con otros relatos báquicos (Blanco, 1978: 39).

Un caso único lo constituye el mosaico del rapto de Europa y de Ganimedes de la calle San Juan Bosco (Fig. 6), en el que se ha figurado en la parte derecha de abajo emergiendo del agua una cabeza báquica, del tipo de las hermae, adornada con corimbos y torques al cuello, detalle iconográfico que lo convierte en un unicum. La cabeza faunística en una de las escenas astigitanas del Rapto de Europa incrementa esa relación de la heroína con lo dionisiaco. Al fin y al cabo, en la literatura mistérica Europa es considerada frecuentemente como una bacante, una mystis de los ritos dionisiacos.

Es más, el mismo Zeus adopta la naturaleza de sátiro para acercarse sexualmente a Antíope. La iconografía más generalizada se utiliza sobre todo en aquellas representaciones en las que la ninfa se presenta como una bacante agachada, las más de las veces de frente y otras de espaldas y es sorprendida por el sátiro en los mosaicos de los Amores de Itálica (Fig.
4) y de Écija (Fig. 1). D. Fernández Galiano (1982: 18-19) cree que en otro panel del mosaico de los amores de Fernán Núñez se ha representado a Zeus/ sátiro y Antíope como dos figuras desnudas, una de un varón intentando alcanzar a la joven, que huye del lecho, con fines amorosos, identificación que no podemos aseverar porque el cuadro se deshizo al intentar extraerlo y solo resta un eros con un arco en su mano izquierda y carcaj colgado a la espalda, sujetando en la otra mano un fulmen o haz de rayos, símbolo de Zeus (Blázquez, 1981: 50-54, lám. 41). El tipo iconográfico responde al de la ninfa sorprendida, que también se utiliza para figurar los mitos de Neptuno y Amymone, Apolo y Dafne. Antíope aparece bajo una iconografía báquica como una ménade/ninfa con tirso y címbalo o pandereta, en los mosaicos de Fuente Álamo (Fig. 15) y Torre de Benagalbón (Fig. 11), siguiendo a Zeus/ sátiro eróticamente en su danza, como preludio de la danza nupcial y semejante a la danza dionisiaca. Una escena muy parecida figura en el mosaico fragmentario de Itálica, en el que, como ya hemos señalado, los personajes se podrían interpretar por sus características, como Zeus/sátiro y Antíope. Ambas figuras están vistas de espaldas dejando ver su sensual cuerpo desnudo (Fig. 12). La joven sujeta con coquetería el extremo del manto mientras que el sátiro sostiene un tirso de gran tamaño y ambos se buscan con una mirada cómplice e íntima, como en el mosaico malagueño, con expresión amorosa. Se trata de escenas en las que no hay acoso sexual, sino seducción y galanteo, manifiesto sobre 


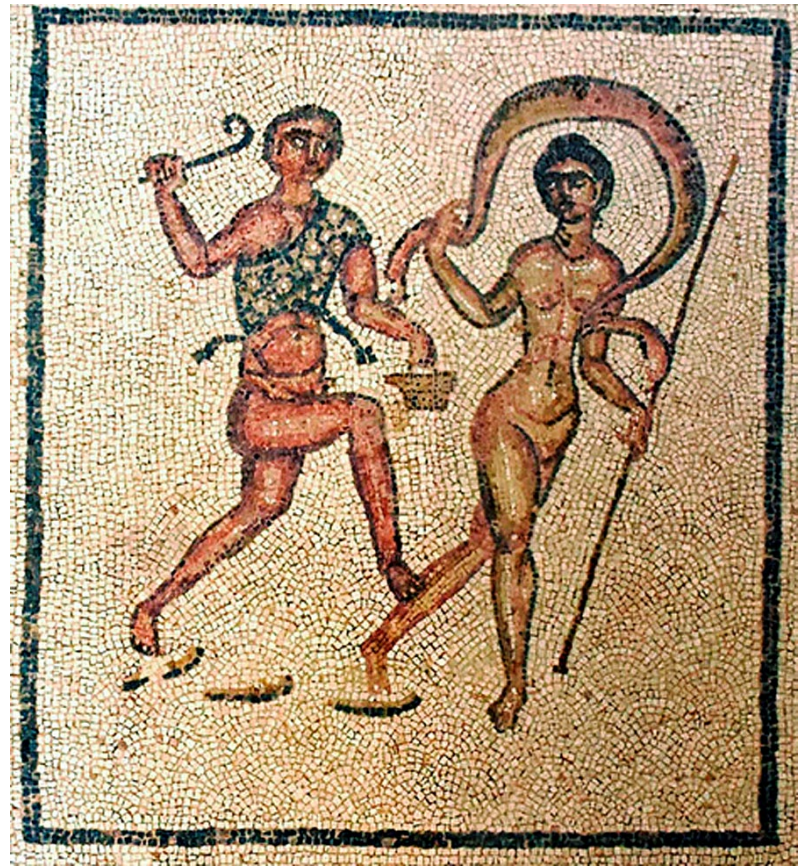

Figura 15: Mosaico de la villa romana de Fuente Álamo. Detalle. Foto cortesía de Alberto Villarejo

todo en la expresión corporal del sátiro. Las fuentes literarias confirman esta ausencia de acoso o de violencia, muy al contrario, hablan de cortejo y de danza nupcial:

«Has oído hablar del embaucador juego amoroso del que fue víctima Antíope, del sátiro riente, de la artimaña de un amante engañoso (...) Zeus el que gobierna en las alturas, tomó una vez la forma de un sátiro, y sedujo a la doncella Antíope bajo una falsa apariencia, con el cortejo engañoso de una danza nupcial» (Nonnos, Dyon. XVI, 240; XXXIII, 301).

La contaminación báquica del mito de Antíope continúa en la última fase del mito que narra la consecuencia de la unión de Zeus/Júpiter y Antíope y el nacimiento de los gemelos Anfión y Zethos, descrita por las fuentes literarias de esta manera:

«Júpiter, oculto bajo la apariencia de un sátiro engendró en la hermosa hija de Niceo (Antíope) dos gemelos (...)» (Ovidio Met. VI, 110-111).

Las relaciones de Dirce con Dionisos parecen con toda seguridad que era el argumento central de la Anthiope de Eurípides y si en el mosaico del Castigo de Dirce de Écija la iconografía no documenta esta conexión (Vargas-Vázquez, López Monteagudo y García-Dils, 2017: 35-37), en los de Sagunto y Pola se halla explícitamente patente. La conexión entre la infancia de Dionisos y la fuente Dirke aparece mencionada en las Bacantes de Eurípides (Bacch. 519-535) y también en las Dionisiacas de Nonnos (Dion. 46, 139-142) se documenta esa relación entre Dirce y Dionisos. En este sentido el toro del castigo de Dirce podría interpretarse como metamorfosis de Dionisos y el mystes de los misterios dionisiacos podría discernir en la figura del toro la imagen misma de Dionisos, el dios tauromorphos al que se rendía culto en Tebas, invocado bajo esta acepción en Las Bacantes de Euripides (v. 1017) y cuyas imágenes, según Plutarco eran frecuentes entre los griegos (Plut. de Is. et Os. 364E).

La contaminación con lo dionisiaco afecta asimismo a los personajes alegóricos de las estaciones en el mosaico de Córdoba (Fig. 7) y también en el del Triunfo báquico de Écija de la Plaza de Santiago (Fig. 10), ambos con la representación de los Amores, en los que se ha utilizado para la alegoría del Otoño el busto de un viejo Sileno.

Es en la colonia Astigi donde más se aprecia esa contaminación iconográfica, temática y programática de los amores de Zeus con la mitología báquica. Ya lo hemos señalado en el Corpus de Mosaicos Romanos de Écija (Sevilla) y volvemos a insistir sobre el tema. Hay una búsqueda intencionada por destacar el sentido alegórico en relación con lo dionisiaco en todos ellos, además de la relación espacial entre unos y otros. Y no son solamente Europa, Antíope y el mismo Zeus que toma la apariencia de un sátiro mientras que Antíope se representa como una bacante, sino que también en el mosaico de los Amores de Écija la presencia de Hermes, encargado de llevar al niño Dionisos de un lugar a otro, primero al monte Nisa y luego a casa de Atamante, para librarle de la vengativa Hera, hace de nexo ideológico entre los amores de Zeus y las escenas dionisiacas representadas en el mismo mosaico. Entre ellas se ha elegido el episodio del descubrimiento de Ariadna por Baco junto a un sátiro/Pan del cortejo a su vuelta triunfal de la India (Vargas-Vázquez, López Monteagudo y García-Dils, 2017: 82; Vargas-Vázquez, 2018: 319), en presencia generalmente de Marón y de eros, siguiendo el relato de Nonnos (Dionisiacas XLVII 265-471) y de Filostrato (Imagines I, 15), esto es el encuentro entre la joven y Baco, lo mismo que ocurre con los amores de Zeus. Un paralelo próximo en cuanto a agrupación temática lo constituye el mosaico del cubiculum n. ${ }^{\circ} 6$ de la Sollertiana Domus de El Djem, que se data a comienzos del s. III d. C., representándose en los cuatro compartimentos a Ariadna dormida, Zeus y Antíope, Leda y el cisne, Ganimedes y el águila (Foucher, 1962: 15-25, pl. XV-XXVI; Blanchard-Lemée, 1995: 254-255, figs. 195-197). Ariadna se ha figurado además con el tipo iconográfico de las fuentes y de las alegorías de la riqueza, ya sea Tellus, Opora u otras (López Monteagudo, 2011: 597-614; San Nicolás, 2011a: 47-60), con objeto de resaltar la prosperidad y la fertilidad de la tierra, dentro de un contexto de carácter báquico que incrementa ese mismo sentido alegórico de destacar la conexión de las imágenes con el ambiente económico de la colonia Augusta Firma Astigi y la importancia de uno de los productos de su economía y comercio, el vino. Así se deduce de las imágenes representadas en sus pavimentos, en los que el lagar ocupa un lugar primordial 
dentro de la composición, no solo en este mosaico de los Amores, sino también en el del Tigerreiter (VargasVázquez, López Monteagudo y García-Dils, 2017: 62-65).

No solamente hay contaminación con la iconografía báquica, sino que la contaminación se extiende también a otros ciclos mitológicos. Baste recordar que en el citado mosaico astigitano con la representación de los raptos de Europa y de Ganimedes (Fig. 6), además de la intrusión del elemento báquico en la cabeza faunística, se aprecia una contaminación entre el rapto de la princesa sidonia y el thiasos marino, al transcurrir la escena en un ambiente acuático, en el que se distinguen varios tipos de peces y moluscos, que no es exclusiva de la Bética, sino que se da en otros lugares, en los que la introducción de elementos marinos como los peces, las nereidas o los tritones, e incluso la presencia de Neptuno y la misma iconografía del toro en forma de animal marino con «cola de pescado», tal como lo describe Nonnos (Dion. I 79-80, 101-102), documentado en los mosaicos de Aquileia, Nîmes, Henchir-Thina y Naxos, produce una cierta confusión a la hora de distinguir a Europa de otras figuras femeninas como las nereidas. Asimismo, la iconografía del velo arqueado sobre la cabeza se utiliza en las nereidas y las ninfas, en las representaciones de Aeternitas o de Natura. La contaminación iconográfica con algunas de estas figuras femeninas ha quedado plasmada también en las fuentes literarias, como Nonnos cuando, al describir la travesía marina de Europa a lomos del toro, dice:

«Al verla, uno creería que es Tetis, o Galatea, o la compañera del que sacude la tierra; o bien supondría que está viendo a Afrodita, sentada sobre la columna de un Tritón» (Nonnos Dion. I 55 ss.)

Desde el punto de vista iconográfico algunas representaciones de Europa, acompañada del séquito triunfante de la procesión marina (Luc. Sam. Dial. Mar. Ix 15,2), se hallan muy próximas a las Venus marinas africanas y es que, como afirma D. Levi, los temas de Europa sobre el toro y del thiasos marino están conectados y son intercambiables (Levi, 1947: 172). Pero es más, la intrusión de un elemento báquico, como es la cabeza faunística dentro del agua, incrementa esa contaminación en este mosaico astigitano en el que se conjuntan unas particularidades iconográficas dignas de resaltar, como son el doble rapto, el thiasos marino y la presencia báquica.

Además del interés iconográfico y artístico de los mosaicos de la Bética con la representación de los Amores de Zeus, hay que resaltar su contenido alegórico conectado con las escenas y personajes báquicos y su contaminación con otras parejas amorosas, Baco y Ariadna, Baco y Dirce, que junto a Zeus y Europa, Zeus y Leda, Zeus y Antíope, Zeus y Dánae, Zeus e Ío, hay que interpretarlas en el sentido que las hierogamias de los dioses con las mortales tienen como alegorías de la fecundidad y riqueza, como origen o germen de topoi y de dinastías entroncadas con la divinidad (López Monteagudo, 2016-2017: 239-248). Este carácter alegórico se pone de manifiesto en la contaminación de las figuras de las Estaciones y de las imágenes dionisiacas con los Amores de Zeus en los mosaicos de Écija (Fig. 1) y de Itálica (Fig. 4), conectando con la misma idea de fertilidad y prosperidad que proporciona el paso del tiempo cíclico, de gran importancia para los romanos. Es una idea acrecentada en el mosaico de Córdoba (Fig. 7), en el que las estaciones de la Primavera y del Invierno se han figurado mediante los bustos de Europa y Ganimedes, mientras que para el Otoño se ha utilizado la figura de un Sileno con corona de hojas de vid. La identificación es segura en el caso de la princesa sidonia, ya que la hierogamia con Zeus tiene lugar en primavera en relación con la energía renovadora que la tierra recibe del cielo a mediados del mes de mayo coincidiendo con la aparición en el cielo de la constelación de Taurus, mientras que Ganimedes, trasplantado al firmamento como signo de Aquarius, podría utilizarse como alegoría del invierno, representada en los calendarios para evocar los meses de enero y febrero como un joven frigio sosteniendo una jarra (López Monteagudo, 1991: 368372). Los tres personajes han sido realizados con ese pathos que caracteriza a las figuras de los mosaicos cordobeses, conseguido con el empleo del color y de los volúmenes, de labios carnosos y mirada directa y profundamente expresiva (López Monteagudo, 1991: 368-372).

\section{CONCLUSIONES}

Del análisis de las imágenes se infiere una lectura que, sobrepasando el ámbito de la iconografía y del arte, se adentra en el verdadero contenido de las mismas, en el mensaje que se quiere transmitir al espectador a través de un juego de ambigüedades.

En opinión de I. Mañas (2011b: 62-63), en estas imágenes la mujer se presenta desde la ideología de género, como objeto del deseo sexual masculino, conseguido mediante el engaño, el cortejo, el rapto, la persecución, que en muchos casos ocultan la violencia sexual contenida en la escena. No obstante, creemos que la voluntaria aceptación por parte de los jóvenes de ambos sexos, expresada mediante el erotismo de su cuerpo desnudo, la danza, el deseo o el placer, los aleja del concepto ideológico actual de agresión sexual. Son imágenes que transmiten el consentimiento de aventuras amorosas de carácter idílico y que, en ocasiones, se justifican por la procreación y la generación de una descendencia.

En los mosaicos con los amores de Zeus de la Bética todo es sensualidad, voluptuosidad, atracción física, aceptación amorosa, entrega, unión carnal, como alegoría de fecundidad, fertilidad, en lo que colaboran también el paso de las estaciones, y preludio de 
riqueza y de prosperidad de uno de los productos de la zona cuya elaboración en lugar preminente queda bien patente en las escenas representadas. Son, por tanto, imágenes parlantes que reflejan el momento en el que fueron creadas, una época de bonanza económica y de bienestar social en todos los órdenes de la vida. Y aunque el tema erótico fue uno de los preferidos del repertorio doméstico de tradición helenística, no solo debemos verlo como una simple aventura amorosagozosa, propia de algunas habitaciones privadas e íntimas como los cubicula, sino como una alegoría de la fertilidad, como una expresión de felicidad y bienestar para los domini de la casa que, al mismo tiempo, manifiestan su riqueza personal y su estatus político-social, utilizando las imágenes míticas con el fin de transmitir un discurso determinado.

Como apuntaba D. Fernández Galiano (1982: 17), la revisión de los mosaicos hispanos deja la puerta abierta hacia nuevas lecturas, interpretaciones y consideraciones, y eso es justo lo que hemos intentado realizar con este trabajo.

\section{REFERENCIAS}

Blanchard-Lemée, M. (1995). Mythes et décors. En Les Sols de l'Afrique romaine (pp. 249-279). Paris: Imprimerie Nationale.

Blanco Freijeiro, A. (1978). Mosaicos romanos de Itálica (I). Corpus de Mosaicos Romanos de España, II. Madrid: Consejo Superior de Investigaciones Científicas.

Blázquez, J. M. (1981). Mosaicos romanos de Córdoba, Jaén y Málaga. Corpus de Mosaicos Romanos de España, III. Madrid: Consejo Superior de Investigaciones Científicas.

Fernández Galiano, D. (1982). Nuevas interpretaciones iconográficas sobre mosaicos hispanorromanos. Museos, 1 , 17-27.

Foucher, L. (1962). Découvertes archéologiques à Thysdrus en 1960. Tunisie: Impr. du Secrétariat d'État aux affaires culturelles et à l'information.

García-Dils, S. y Ordóñez, S. 2019. El mosaico de los Amores de Zeus de la Plaza de Armas de Écija. Un nuevo pavimento musivo de colonia Augusta Firma. Écija: Real Academia de Ciencias, Bellas Artes y Buenas Letras «Luis Vélez de Guevara».

Levi, D. (1947). Antioc Mosaic Pavements. Princeton: Princeton University Press.

López Monteagudo, G. (1991). El mosaico de las estaciones de Córdoba. Trabajos de Prehistoria, 48, 368-372. DOI: https://doi.org/10.3989/tp.1991.v48.i0.534

López Monteagudo, G. (2010). Mosaicos romanos de la Bética. En P. León (Coord.). Arte romano de la Bética III (pp. 16-189). Sevilla: Fundacion Focus-Abengoa.

López Monteagudo, G. (2011). Opora through East and West. Abundance Allegories in Mosaics of Spain and Turkey. En
M. Sahin (Ed.). 11th International Colloquium on Ancient Mosaics (pp. 597-614). İstanbul: Zero Books.

López Monteagudo, G. (2016-2017). Mito y viaje. Leyendas fundacionales en la Antigüedad clásica. Anas, 29-30, 239-248.

López Monteagudo, G. y San Nicolás Pedraz, M. ${ }^{a}$ P. (1995). El mito de Europa en los mosaicos hispano-romanos. Análisis iconográfico e interpretativo. Espacio, Tiempo y Forma, Serie II, Historia Antigua, 8, 383-438. DOI: https://doi. org/10.5944/etfii.8.1995.4272

López Monteagudo, G. y San Nicolás Pedraz, M. ${ }^{a}$ P. (1996). Astarté-Europa en la Península Ibérica. Un ejemplo de interpretatio romana. En M. ${ }^{\mathrm{a}} \mathrm{A}$. Querol Fernández y M. ${ }^{\mathrm{a}} \mathrm{T}$. Chapa Brunet (Coords.). Homenaje al profesor Manuel Fernández Miranda (pp. 451-470). Complutum Extra, 6, 1. Madrid: Universidad Complutense.

Mañas, I. (2010). Pavimentos decorativos de Itálica (Santiponce, Sevilla). Un estudio arqueológico. Oxford: John and Erica Hedges Ltd. DOI: https://doi. org/10.30861/9781407304809

Mañas, I. (2011a). Mosaicos romanos de Itálica (II). Corpus de Mosaicos Romanos de España, XIII. Madrid - Sevilla: Consejo Superior de Investigaciones Científicas - Universidad Pablo de Olavide.

Mañas, I. (2011b). Representaciones culturales de la violencia de género: acoso, rebeldía y sumisión en el mosaico romano. En L. Neira (Coord.). Representaciones de mujeres en los mosaicos romanos y su impacto en el imaginario de estereotipos femeninos (pp. 61-71). Madrid: Creaciones Vincent Gabrielle.

Mañas, I. y Vargas-Vázquez, S. (2007). Nuevos mosaicos hallados en Málaga: las villas de La Estación y de La Torre de Benagalbón. Mainake, 29, 315-338.

San Nicolás Pedraz, M. ${ }^{a}$ P. (1999). Leda y el cisne en la musivaria romana. Espacio, Tiempo y Forma, Serie I, Prehistoria y Arqueología, 12, 347-387. DOI: https://doi.org/10.5944/ etfi.12.1999.4690

San Nicolás Pedraz, M. ${ }^{a}$ P. (2005). Sobre una particular iconografía de Leda en el mosaico hispano de Écija. En $L a$ mosaïque gréco-romaine, $I X$ (pp. 975-985). Collection de l'École Française de Rome, 352. Roma: École Française de Rome.

San Nicolás Pedraz, M. ${ }^{a}$ P. (2005-2006). Iconografía de los Amores de Zeus. Análisis de los mosaicos hispanorromanos. Boletín de la Asociación Española de Amigos de la Arqueología, 44, 239-257.

San Nicolás Pedraz, M. ${ }^{\text {a }}$ P. (2006). Iconografía de la «trulla/ cazo» de El Faro de Cullera, Valencia. En J. M. Maillo y E. Baquedano (Eds.). Miscelánea en homenaje a Victoria Cabrera (pp. 148-157). Zona Arqueológica, 7, 2. Madrid: Museo Arqueológico Regional.

San Nicolás Pedraz, M. ${ }^{\text {P }}$. (2010). Zeus/Júpiter y Antíope en los mosaicos romanos. Espacio, Tiempo y Forma, Serie II, Historia Antigua, 23, 497-518. DOI: https://doi.org/10.5944/ etfii.23.2010.1778 
San Nicolás Pedraz, M. ${ }^{a}$ P. (2011). Los amores de Zeus/ Jupiter en los mosaicos romanos de Hispania. En La mosaïque gréco-romaine, $X$ (pp. 323-342). Collection de l'École Française de Rome. Roma: École Française de Rome.

San Nicolás Pedraz, M. ${ }^{a}$ P. (2011a). Ariadna, entre el desengaño y el amor. En L. Neira (Coord.). Representaciones de mujeres en los mosaicos romanos y su impacto en el imaginario de estereotipos femeninos (pp. 47-60). Madrid: Creaciones Vincent Gabrielle.

Vargas-Vázquez, S. (2018): Cube Designs in Roman Baetica Mosaics. Journal of Mosaic Research, 11, 315-331. https:// doi.org/10.26658/jmr.440632
Vargas-Vázquez, S., López Monteagudo, G. y García-Dils, S. (2017). Mosaicos romanos de Écija (Sevilla). Corpus de Mosaicos Romanos de España, XIV. Madrid - Écija: Consejo Superior de Investigaciones Científicas - Real Academia de Ciencias, Bellas Artes y Buenas Letras «Luis Vélez de Guevara».

Vargas-Vázquez, S., López Monteagudo, G. y San Nicolás Pedraz, M. ${ }^{\mathrm{a}}$ P. (e.p.). Consideraciones sobre los mosaicos mitológicos de la Bética. Archivo Español de Arqueología. 